\title{
Near-Death Experiences: Some Logical Problems and Questions for Further Study
}

\author{
Stephen Vicchio \\ Department of Philosophy \\ Notre Dame College of Maryland
}

\section{INTRODUCTION}

Both sections of this paper serve as an attempt at clarifying the logical status of related phenomena known as near-death experiences (NDEs). In the first part of this paper five logical problems are discussed that may have direct bearing on any attempts at forming a logically coherent interpretation of near-death experiences. In the second section a number of questions relevant to NDEs are raised that may be deserving of some further study.

The Problem of the Fallacy of Misplaced Concreteness

Much of the literature on NDEs is full of seemingly straightforward statements like, "X died but then was resuscitated." Apparently simple statements like these may in fact be at the heart of a great deal of confusion about many contemporary discussions of life after death. Problems arise because we tend to assume that death is an event. In fact, we tend to shift rather uneasily from the noun, death, which is thought of as an event, to the verb, dying, which is construed as a process. This view of death as an event seems to be deeply ingrained in the Western mind. It only apparently has the merit of common sense because the structure of our language renders reification easy to believe. The word dead, since it exists in the language, would seem to be a term that names a "thing" in the same way the "Empire State Building" names something. It does not seem strange to say that since "deadness" has a name, it exists, it is a thing. But this reification is dangerous. This view of death as an event or thing is implicitly assumed in much of our art and literature and, more importantly, our legal system and medical practice. We often tend figuratively, and sometimes literally, to see death as a "grim reaper" or an "exterminating angel." These kinds of uses of the word death 
fall into what Whitehead has called "the fallacy of misplaced concreteness," or regarding an abstraction as if it were a thing.

The repercussions of this view should be clear. If we view death as an event, it occurs instantaneously. The genesis of this mistaken idea can be found in a time prior to a clear understanding of the distinction between clinical death and cellular death. Clinical death is nothing more than an abstract set of descriptions for the absence of various vital signs. It is quite possible to be clinically "dead" one moment and clinically "alive" the next. Indeed, it happens in openheart surgery all the time. In patients who are not resuscitated, "cellular death" follows "clinical death." But "cellular death" is also not an instantaneous event or reification. It is a process that develops according to a set of quite complex variables-temperature, original physical health of the patient, blood/oxygen supply to various organs, etc. The difference between clinical and cellular death, however, is that once the process of cellular death is well on the way to completion, most of the major organ systems of the body have begun to break down. When this begins to occur, "life," an abstraction used to label the sum of the metabolic activities by which an organism grows, reproduces, etc., is irrevocably lost.

The immediate import of all this should be clear: Many researchers and theorists writing on NDEs may be calling a person "dead" when in fact he is involved in the process of death, and this process, at least to a certain extent, appears to be reversible.

\section{The Problem of Parallels}

In much of the literature on NDEs there is often a tendency to use parallel descriptions and experiences, often from ancient literature, for the purpose of proving the transcendental character of these experiences. Raymond Moody (1975), in his short chapter on parallels, serves as a good example. He makes a number of references to the Bardo Thodol (1960), the Tibetan Book of the Dead. A close reading of the Tibetan text reveals that at the moment of death a lama reads the Thodol to the dying person; the reading ostensibly describes the events that take place after death. The purpose of the instruction is to guide the soul of the deceased and to impart certain knowledge that can facilitate the soul's travel. Moody correctly points out this description has a number of important similarities to the accounts offered by the subjects in his research.

Other researchers have stressed the similarity of contemporary near-death experiences to accounts given in "The Dream of Scipio" (1967), the conclusion to Cicero's On the Republic. In this work 
Cicero tells us, through the character of Scipio, of a panoramic vision coming as the result of a close brush with death. In this vision Scipio is met by Scipio Africanus, the Elder, a dead ancestor who guides him in to paradise.

James Hastings' Encyclopedia of Religion and Ethics (1928) contains a number of other cross-cultural examples of out-of-body experiences associated with NDEs. In one of these stories a dead Chippewa chief is carried home after battle. Along the way he separates from his body, and after several unsuccessful attempts to reenter his body, he returns in this spirit form to the battlefield. In despair, he finally cries, "I am seeking to return to my body." With a desperate effort he darts through what he sees as a flame that separates him from his body. Sometime later he awakens in his weakened body to tell of the ordeal. Similar accounts can be found in Orphic literature, Plutarch, many of the principle Upanisnads, the Zoroastrian's Bundahishn, and the work of the 18th-century Swedish mystic, Emanuel Swedenborg.

I have no problem with any of these examples being used as indications that experiences similar or even parallel to the current literature can be found in ancient texts, but I think it would be a mistake to necessarily interpret them as confirmations of the fate of the dead.

Moody (1975) seems to have a dim awareness of this himself; he offers one possible explanation for the parallels, as well as a rejoinder:

Is it possible that the near-death experiences I have collected were influenced by works of the kind which I have discussed? All of the persons with whom I have talked had some exposure prior to their experiences to The Bible, and two or three know something about the ideas of Plato. On the other hand, none were aware of the existence of such esoterica as the works of Swedenborg or The Tibetan Book of the Dead. Yet, many details which do not appear in The Bible, or even in Plato, constantly crop up in the accounts which I have gathered, and these correspond exactly with phenomena and events mentioned in the more unusual sources (p. 88).

He continues by implicitly suggesting that there is something quite remarkable about these parallel accounts:

It must be acknowledged that the existence of the similarities and parallels among the writings of ancient thinkers and the reports of modern Americans who survive close brushes with death remains a striking, and, so far, not definitively explicable fact. How is it, we might well ask ourselves, that the wisdom of Tibetan sages, the theology and visions of Paul, the strange insights and my ths of Plato, and the spiritual revelations of Swedenborg all agree so well, both among themselves and with the narratives of contemporary individuals who have come as close as anyone alive to the state of death (p. 89).

Although his position is more implicit than explicit, he seems to 
believe that not only is the structure of these contemporary and ancient stories the same, but their interpretation is the same as well. But there are some serious logical problems with this point of view.

Doubtless, cases of NDEs are more numerous today as the result of advances in medical technology, but we must not be naive enough to assume that the ancient world could not have had its share of these experiences as well. When we are resuscitated today, we most often give credit to the extraordinary accomplishments of medical personnel and accompanying equipment. In ancient times, NDEs might very well have been interpreted as revealing something terribly profound about the mysteries of death, when in fact the proper interpretation of those ancient experiences may have nothing to do with what happens after death at all.

\section{The Problem of the Genetic Fallacy}

There is another way of looking at this problem of parallels that is just as illogical. It is usually made by reductionists who suggest that near-death experiences can be explained in terms of purely natural factors, usually psychological or physiological-nervous disorders, frontal lobe disorders, repressed desires, auto-suggestion, hy pnogogic or hypnopompic sleep, and so on. In order to understand what this second parallel thesis amounts to, let us consider the following example from Teresa of Avila (1946):

Often when the soul least expects it, our Lord calls her suddenly. She hears very distinctly that her God calls her, and it gives her such a start, especially at the beginning, that she trembles and utters plaints. She feels that an ineffable wound has been dealt her and that the wound is so precious in her sight that she would like it never to heal. She knows that her divine Spouse is near her, although $\mathrm{He}$ does not let her enjoy $\mathrm{His}$ adorable presence, and she cannot help complaining to $\mathrm{Him}$ in words of love. The voice of the Well-Beloved causes in the soul such transports that she is consumed by desire, and yet does not know what to ask, because she sees clearly that her Lord is with her. What pains could she have? And for what greater happiness could she wish? To this I do not know what to answer; but that of which I am certain, is that the pain penetrates down to the very bottom of the bowels, and that it seems that they are being torn away when the heavenly Spouse withdraws the arrow with which he has transpierced them. As long as that pain lasts, it is always on the increase or on the decrease, it never remains at the same intensity. It is for that reason that the soul is never entirely on fire; the spark goes out and the soul feels a desire stronger than ever to endure again the love-pain she has just experienced (p. 119).

As you can see, this experience contains at least some of the core elements of NDEs. It is an important example, however, because of 
what many reductionists would say about a young woman like Teresa who had taken a lifelong vow of chastity. A reductionistic interpretation of this experience might say something like the following: Natural desires for sexual love have been inhibited and repressed from consciousness. Nevertheless, these desires are active in the unconscious and press for some kind of fulfillment. Since they cannot be expressed in a direct way, they achieve satisfaction through a delusory experience of the presence of a male deity. Of course, it might be added that not all religious experiences, of which NDEs are just a small part, provide such easy targets for the reductionists.

Various questions can be raised as to the cogency of these kinds of explanations. The most obvious is that at best these interpretations are purely speculative in nature. Social scientists often take principles established in other contexts and apply them to near-death experiences. Eventually these applications must stand a more rigorous test.

The real problem with reductionistic explanations of NDEs, however, lies not in a lack of empirical data, but rather in what the data are believed to show. In short, reductionists believe that if you can show parallel or phenomenologically similar experiences in which there are known psychological or neurophysiological determinants, then any theological interpretation of NDEs is specious. This point of view is often expressed in terms of pointing out the phenomenological similarity between NDEs and certain drug-induced hallucinatory experiences. One interesting point about these drug experiences is that they are not solely a product of the 1960's. William James, at the beginning of this century, called attention to the use of nitrous oxide as a source of religious experiences. There are also many ancient as well as modern religious traditions that have used similar drugs for such purposes. The important philosophical question is this: What relationship, if any, do these kinds of parallel experiences have to non-drug-induced NDEs?

Bertrand Russell (1935) had a rather reductionistic answer to this question:

From a scientific point of view, we can make no distinction between the man who eats little and sees heaven and the man who drinks much and sees snakes. Each is in an abnormal physical condition, and therefore has abnormal perceptions. Normal perceptions, since they have to be useful in the struggle for life, must have some correspondence with fact; but in abnormal perceptions there is no reason to expect such correspondence, and their testimony, therefore, cannot outweigh that of normal perception (p. 188).

Russell's point of view raises some important issues. But before moving to them we must first note an important distinction. Reduc- 
tionists must decide whether they want to say that NDEs spring from abnormal states or the much weaker claim that experiences similar NDEs are known to occur in abnormal states. If they are making the latter claim, then these assertions amount to very little. Patients in mental institutions often claim to be in touch with Jesus, Moses, and like figures, in ways that are similar to NDEs. But this does nothing to show that theological interpretations of NDEs are specious, any more than my intoxicated friend having an experience similar to those involved in the ordinary perception of an elephant would prove that all experiences of elephants are delusions, or, more importantly, that elephants don't exist.

But Russell seems to be arguing the harder line, namely, any religious experience is the result of an abnormal state of consciousness. How one might go about establishing a claim like this is, of course, problematical. However, for the sake of the reductionist's argument, let's assume it is true. It is still logically possible, even if Russell's assertion is true, that the way God chose to reveal himself to human beings is through these abnormal states of consciousness. As long as this position is logically possible, the reductionist's point of view cannot be a necessary conclusion.

\section{The Problem of the Possibility of Transitoriness}

One interesting point about NDEs that seems to have been totally ignored in the literature is this: If we were to accept these reports as constituting evidence for survival after death, it would not necessarily follow that we survive death for all eternity. It could be the case that survival after death, if it does exist, is a transitory experience, lasting a short time. Indeed, it may be the case that God has decided to let us go out with a real treat that lasts for only an instant. It does not necessarily follow that if $\mathrm{X}$ believes that NDEs provide evidence for survival after death that $X$ must also be committed to the claim that this form of survival will last forever.

\section{The Problem of Paradigm Shifts}

Not too far down the road it may be the case that adjustments in some of our scientific assumptions will be required for us to understand these experiences more fully. But this kind of realization is different from arguing that some overarching paradigm shift need occur in our thinking in order to begin to make clear interpretations of these phenomena. Expressions like "a new scientific revolution" and "a shift in our most fundamental scientific categories" are all too often used in the NDE literature to exhort people to think more 
open-mindedly about these experiences.

Most often these discussions of "paradigm shifts" proceed from some insights of Thomas Kuhn (1962):

Each innovator necessitated the community's rejection of one time-honored scientific theory in favor of another incompatible with it. Each produced a consequent shift in the problems available for scientific scrutiny and in the standards by which the profession determined what should count as an admissible problem or as a legitimate problem-solution. And each transformed the scientific imagination in ways that we shall ultimately need to describe as a transformation of the world within which scientific work was done. Such changes, together with the controversies that almost always accompany them, are the defining characteristics of scientific revolutions (p. 14).

According to Kuhn, paradigms become "supertheories," theoretical formulations covering a wide range of data and organizing it into a consistent and coherent body of knowledge. Paradigms begin to shift when these supertheories no longer retain their overarching explanatory value, and other theories begin to compete with the original supertheory. I must confess that I frankly am not all that sure that there has been any shifting of fundamental scientific categories vis-à-vis NDEs, and if there were, I'm not so sure that we have been clear enough about Kuhn's rather murky language that we know what a scientific paradigm is in order to recognize when new ones come along. Indeed, a proper understanding of the nature of scientific inquiry, as well as a grounding in formal logic, might go a long way in persuading "paradigm shifters" that the old categories of understanding may do quite nicely in analyzing NDEs. What frequently seems to happen is that there is a good deal of the closing of eyes to evidence alleged against something one believes in. The result is often a kind of deduction of facts from principles, instead of inducing principles from facts. When Galileo invited astronomers of his time to view the moons of Jupiter through his telescope, some refused on the grounds that if they saw anything it would be an illusion, no doubt diabolical, since the number of heavenly bodies had already been established. Of course, the astronomy of the time allowed no provisions for the discovery of new heavenly bodies. Perhaps this story tells us more about a certain cast of mind than it does about the need for new scientific paradigms. When confronted with closed-minded people, one feels helpless, for no amount of evidence seems to be clinching. Frequently, the facts are just plain ignored or simply brushed aside as irrelevant. This approach often offends people of a more empirical cast of mind. Empiricists are supposedly ready to throw out principles that don't fit neatly with 
the evidence. Yet, ironically, when it comes to the study of NDEs, empiricists often suffer from the same kind of a priori thinking they accuse the religionists of. A cure for this malady is probably to be found in the cultivation of open-mindedness and not necessarily in the tooling out of new "scientific paradigms."

Another problem in this shifting of paradigms is that a careful analysis of those "new models" offered to explain NDEs often shows that the models themselves are logically confused. One of the supposed shifts involves the use of the work of Karl Pribram (1971, 1976 ) on perception and memory in constructing a new "scientific paradigm" for viewing the world in general and NDEs in particular. The key feature of Pribram's work is that he has suggested that the inherent structures of the world may be analogous to the interference patterns on a hologram. The brain, in Pribram's view, is the instrument by which human beings receive the messages from this holographic reality and translate it in to our familiar three-dimensional reality. Recently there have been at least two attempts to develop interpretations of NDEs through the use of Pribram's theory. I need not spend time here detailing the connection between Pribram and the NDE theorists who use his theory. All that need be done is to show that the holographic model of perception may rest on some old mistakes. If that can be demonstrated, it would be ill advised to think of Pribram's theory as a shifting in paradigms.

The problem with holographic theories of perception has been skillfully pointed out by Stephen Braude (in press). Professor Braude essentially argues that Pribram's theory is both reductionistic and atomistic. Implicit in Pribram's model is the notion that reality can be reduced to atomic parts, in this case, to frequencies forming interference patterns. As Braude points out, Pribram sees these frequencies as "atomic or basic in the sense that they are building blocks for our familiar perceptual and experiential reality."

An important point to understand about this claim is that the structure of nature is not just analogous to these interference patterns of the hologram, it is the stuff of which the ordinary threedimensional perception of reality is made. As Braude points out, Pribram's point of view essentially involves two basic assertions about the way reality is:

1. Nature is made up of atomic parts analogous to frequencies on a hologram.

2. Our ordinary perceptions are ordered arrangements composed of these atomic parts.

Both 1 and 2 rest on a fundamental mistake. The mistake involves 
assuming that there is some most fundamental way of parsing the parts of the world. Once again, Braude is helpful on this point:

To see what is wrong with the idea that nature has a preferred parsing, ask yourself the question: How many things are in this room? The important fact to observe here is that this question has no single correct answer. Before we can answer it, we need some idea of what is to count as a thing. And it is crucial to realize that different sorts of objects or entities may legitimately count as things in different contexts. Independently of some context in which certain descriptions of the room but not others count as appropriate, the question simply has no answer. If we are atomic physicists, we might consider atoms or constituents of atoms to be things. And in that case the room will contain an enormous number of things. If we are household movers or insurance agents, however, there may be far fewer things in the room. Moreover, it is clear that similar considerations apply to any given object-say, a table or a hand. Of any object $X$, we may ask, 'What are the elements of $X$ ?,' and different sorts of things will count as elements in different contexts. Thus, an artist, physician, chemist, and physicist might give different inventories of the things composing a human hand. Thus, even when we agree that the hand is composed of things, there is no preferred list of things-i.e., no set of hand-components that is absolutely more fundamental than any other set.

In order to make this clear, Wittgenstein apparently used to exhort his students to see that "language only makes sense in the mouth of a man." What I think he meant is that language and perception only make sense in the context in which they are uttered or thought. If this is the case, there can be no one more fundamental parsing of reality. An example might be of some help on this point.

Suppose Mrs. X, an artist and sculptress, calls her husband, an anal-retentive CPA, for the purposes of discussing a robbery that has recently occurred at their home. Both are concerned with generating an accurate list of the things taken from Mrs. X's studio. As the sculptress begins to develop her list, she thinks about one of her pieces that has been taken. It consists of several metal trash cans tied together with chicken wire, supposedly symbolizing the plight of the 20 th-century woman. When Mrs. X makes her list, she writes, "One sculpture: The Plight of the 20th-Century Woman."

Now Mr. X is a pragmatic sort. When he writes his list, it reads, "Six (6) ten (10)-gauge aluminum fifty (50)-gallon trash cans; $34 \mathrm{ft}$. of $1 / 4$ in. chicken wire; six (6) 15 in. aluminum trash can lids."

This example should serve to illustrate a crucial point. What Mrs. X is thinking cannot be explained solely in terms of the structure of what is happening within her, that is, the structuring of her mental imagery. The same mental image for Mrs. X produces a different thought for Mr. X because the context in which he views it (them) is 
quite different from his wife. What our mental images represent function differently in different contexts and result in different thoughts, even though the mental imagery may essentially be the same. Thus, we begin to see what Wittgenstein meant by language only making sense in the mouth of a man, as well as why holographic theory is a deceptive and inadequate model for the way perception works. Needless to say, the analysis of these kinds of mistakes is a terribly complicated matter; for a more detailed description of the logical problems inherent in holographic interpretations of NDEs, I direct you to Braude's excellent article mentioned in the bibliography.

Ironically, even if this holographic model of perception were a cogent explanation for near-death experiences, it reduces to a curious genus of the mechanistic species, a scientific paradigm that has been around at least since the time of the pre-Socratics.

In addition to the five logical problems mentioned in part I, I would also like to make a few comments on some questions concerning NDEs that may be worthy of some further study.

Why do some individuals retum with stories to tell while others remember nothing?

Figures from Noyes (1976), Kastenbaum (1979), Ring (1980), and Sabom and Kreutziger (1977) suggest that, at a minimum, about 40 percent of people in life-threatening situations experience at least some of the components of the classic NDE. One may quibble with this figure on a number of fronts, the principle one being that at this point in near-death research all literature has consisted of self-selected samples. In a more random selection process this figure of 40 percent may be much lower.

Leaving these problems aside, however, one might ask a different question: Why don't the other 60 percent have classic NDEs? An answer to this question might lead us in many different directions. One argument that might be given is that only certain people actually survive death. This same point is raised rather clearly by Kastenbaum (1979):

If one or a few, why not all? Grant the possibility that what seem to be ghosts or apparitions are sometimes ghosts or apparitions. The sightings appear to be relatively uncommon when we consider the frequency of death itself. One could ask the usual question: How could there be any ghost, even one, any time, under any circumstance? Or could one ask a different question: If there are perhaps ghosts on occasion, why not more 
often? Why doesn't every deceased person yield a spirit that is somehow perceived by the survivors? A similar inquiry may be lodged of the "discarnate minds" that have occasionally seemed to communicate through "mediums" in a reasonably convincing fashion. Why don't we hear from the dead all the time, or at least more commonly? Is the problem the short supply of authentic mediums? The inability or lack of fine tuning that keeps most of us from receiving messages? Can it be that only a few deceased people choose to communicate, or that only a few can? More radically, perhaps: Is it the case that a few humans survive death in some form, but that most do not? This concept is not entirely unknown (for example, Hocking's theory of "conditional immortality"). It would raise a problem for most people who are accustomed to thinking in terms of general laws or principles that govern the universe. What goes up must come down-but only sometimes! One and one make two, but sometimes three, and sometimes make nothing at all! Twentieth-century science (notably theoretical physics) has provided us with alternative conceptions of the universe that still do not seem at home with our intuitive or conditioned sense of "how things really are." Possibly, some people die and stay dead while others do not. Such a notion would take some getting used to, At the moment it stands as one more obstacle to accepting survival explanations of phenomena such as apparitions and mediumistic communications (pp. 180-181).

Rawlings (1978) has theorized that many near-death survivors who have no recall are actually repressing hellish experiences. Kenneth Ring ${ }^{1}$ has also suggested that since NDEs seem to take time to develop, some people may be brought back before the process could unfold. Ring has also pointed out that the recall of NDEs may be analogous to the recall of dreams-some people wake up in the morning and remember, while others do not.

What is the relationship of religious background to the interpretation of near-death experiences?

Osis (1961) and Osis and Haraldsson (1977) report visions of religious figures, dead family members, and deceased friends as important components of the NDE. Ring (1980), Kubler-Ross (1976), and Sabom and Kreutzinger (1977) report similar findings. Most of these researchers tend to interpret these visions as glimpses of the afterlife. Rodin (1980) believes these experiences may be structured by previous cultural and religious conditioning. Osis and Haraldsson (1977), Sabom and Kreutzinger (1977), and Ring (1980) disagree, pointing out that many of the people having these visions were not at all religious. Ring (1980), for example, claims that neither the likelihood nor depth of near-death experiences is systematically related to individual religiosity. This assertion seems to be based on the selfevaluation of religiosity by the subjects in Ring's study, but I wonder 


\section{Some Logical Problems and Questions}

if this issue isn't more subtle than asking even well-meaning and honest people whether or not they believe in God. The use of an "index of religiosity questionnaire" may be confusing because it implicitly ignores the distinction between considering oneself to be nonreligious and participating in a cultural context where although an individual may be a nonbeliever, he may still be well aware of the myths, symbols, and rituals that inform the lives of the devout in his culture. Using Ring's analysis, it would seem impossible for most of us to dream of Santa Claus, since in our waking state most of us no longer believe in the existence of the jolly fellow with the red suit. But this is clearly wrongheaded. We often dream of fairies, unicorns, and an assortment of other mythic creatures, even though in our waking state we are quite dubious of their existence. Kalish (1979) has suggested that group identification and cultural background may have a great deal to do with how subjects interpret NDEs. This question certainly deserves more careful cross-cultural study than it has so far been given.

What is the relationship between NDEs and near-death suicides?

To this point the literature attempting to answer this question has been quite disappointing. The best-known attempt at dealing with this issue is Moody's (1977) seven-page chapter in Reflections on Life After Life. In the beginning of that chapter he informs us that he wishes to address himself to two questions:

Do persons who have had near-death experiences from causes other than suicide attempts come back with any particular attitude toward suicide?, and Do reported near-death experiences which resulted from suicide attempts differ in any way from those that had other causes (pp. 43-44)?

Moody answers the first of these questions by asserting that although many of his subjects felt they did not want to "come back from the dead," they all disavowed suicide as a means of returning to death. He mentions one man who had "died" in an accident:

While I was over there, I got the feeling that two things it would be completely forbidden for me to do would be to kill myself or to kill another person .... If I were to commit suicide I would be throwing God's gift back in His face ... Killing somebody else would be interfering with God's purpose for that individual (p. 44).

He answers the second query about the experiences and attitudes of the suicide attempters by claiming the same kind of unanimity:

All mentioned that after their experiences, they would never consider trying suicide again. Their common attitude is that they had made a mistake, and that they were very glad they had not succeeded in their attempts (p. 46). 
It should be clear that Moody is telling us in no uncertain terms that suicide is a morally reprehensible act. Indeed, considering the surroundings in which the suicide victims find themselves, one could argue Moody sees suicide as a damnable act. Moody quotes a man who was despondent over the recent death of his wife. The man "died" as the result of a gunshot wound, and was resuscitated.

I didn't go where my wife was. I went to an awful place ... I immediately saw what a mistake I had made . . . I thought, 'I wish I hadn't done it (Afterword).'

Moody spends the remainder of his short chapter on suicide attempting to marshal support for this moralistic position by quoting Plato, John Locke, Thomas Aquinas, and Immanuel Kant, who all argue, with varying degrees of plausibility and effectiveness, that suicide is morally reprehensible, and that the victim "arrives in the other world as one who has deserted his post; he must be looked upon as a rebel against God." Moody later parenthetically adds he "does not present the above arguments to endorse the reasoning or to make an ethical or moral judgement about suicide." (p. 47) But if this is not his purpose, one can only wonder what it might be. Nevertheless, in the final few pages of this chapter, he does raise some subtle and important points about suicide and survival after death.

I realize that the experiences I have quoted in this chapter raise many questions. Some have pointed out that in certain cultures suicide is not morally condemned, as it is in our own ... Some persons commit suicide for altruistic reasons, to save others, for example. What would people who undergo such 'heroic' deaths experience? Or what of the people who take their own lives in the throes of psychotic depression or horrendous loss (pp. 47-48)?

It is important to see that Moody's position on suicide is more implicit than explicit. Indeed, he seems to be reformulating a rather old argument and clothing it in the validity of personal experiences and sage philosophers.

Moody seems to be making two important claims about the relationship between religion and morality. First, if we can establish that there is a God who will punish us for committing suicide, then we have a good reason for not doing so. There seems to be an underlying principle which gives this point its validity. That is, human beings are often motivated to perform right actions and refrain from wrong ones because of a belief in heaven and hell.

From the moral standpoint this point of view suffers from some problems. In order to understand these, consider the following example. 
Suppose Mr. Y gives a very large sum of money to the United Way. All other things being equal we would ordinarily think highly of Mr. $Y$ and the action he has performed. The action raises his moral stock; it makes him an exemplary individual. But suppose later on we find out that he had given the money for two reasons: first, he was promised double the sum he gave if he performed this act of charity, and second, he was told that his hands would be chopped off if he didn't give it. What would our reaction be to Mr. Y, knowing these two new facts? We might still be very happy he gave the money, but we would no longer think in such laudatory terms of Mr. Y. Now when Moody implies that we should be motivated to perform right actions and refrain from wrong ones because of a belief in heaven and hell, he is essentially advocating a position that our motives be like those of Mr. Y's. Although it may be the case that religious people believe that God will punish the evil and reward the good, it seems they should oppose the view that these rewards and punishments give us reasons for acting morally.

Moody's second point is perhaps more fundamental than the first. Simply put, it is this: The way we know that suicide is wrong is because God is clearly telling us so. We avoid the problem of conflicting religious points of view on suicide, for we have a genuine Divine revelation, a glimpse of the great beyong, as a source of moral certainty. This second claim would also seem to rest on a more general ontological principle that morally right and morally wrong actions are commanded and forbidden by God.

In the Euthyphro (Plato, 1950), Socrates challenges someone who held both of these general principles to be true at the same time. He asks his companion whether the view that an act is right because it is willed by God is compatible with the position that God wills an act because it is right.

Socrates argues that God is by definition a "morally perfect being." The proof of this is that no one would call a being "God" unless the being were morally perfect. To make this point clear, he offers the example of a triangle which we would refuse to call a triangle unless it were a three-sided figure whose angles equalled $180^{\circ}$.

It follows, then, that to know any being is "God," we must first know if that being is "morally perfect." But if moral goodness is determined according to God's will, or if any act is right or wrong simply because God wants it that way, then we have to know that God exists and what he wills before we can know what is morally good.

Thus, if we hold both that God is, by definition, "morally good" and that God's will defines moral goodness, we find ourselves in a 
peculiar position. We cannot determine whether God exists until we have determined first (and independently) what moral goodness is. But we cannot determine what moral goodness is because, by definition, "moral goodness" is what God wills it to be.

It may well be that Moody would ignore this discourse, claiming that since we have direct knowledge of God through these near-death experiences, these arguments do not apply. But this is clearly not a valid objection. Consider the following example: Suppose while attempting to drown myself, in the midst of that twilight between life and death, a form suddenly appears stating he is God. Suppose the form declares that Moses was a false prophet whose ten commandments were really the handiwork of the devil. The form then announces the "true commandments: commit murder, tell lies, break promises, and kill yourself."

Needless to say, if this happened to us, most of us would reject figure's claims. Why? Because what this form commands us to do is clearly evil. But if any act is right simply because God wills it, we are not justified in rejecting the possibility that this figure could be God. It is a mistake to believe that we get our ideas of right and wrong from God. Rather, it is in light of our ideas of right and wrong that we frame our notion of God. This certainly makes sense from the standpoint of developmental psychology. Few mothers would teach their children about God first and then about not playing on the steps.

What implications does all this have for Moody's view of suicide? One obvious repercussion is that the general ontological principle on which his second claim is based is obviously false. If we say that suicide is wrong simply because God says so, then we have admitted that right and wrong are grounded on something other than the will of God. Perhaps Nielson (1959) put it best:

No information about the nature of reality, the state of the world, or knowledge that there is a God and that he issues commands, will by itself tell us what is good or what we ought to do. The statement 'God wills X' is not a moral pronouncement. Before we know whether we ought to do $X$, we must know that what God wills is good. And in order to know what God wills is good, we would have to judge it, for otherwise, it would be rhetorical to ask, 'Is what God wills good?' But it is not rhetorical to ask that question. 'God wills $X$ ' or 'God commands $X$ ' is not equivalent to ' $X$ is good' in the same way as ' $X$ is a male parent' is equivalent to ' $X$ is a father.' 'God wills it, but is it good?' is not a senseless or self-answering question like 'Fred is a male parent but is he a father?' The moral agent must independently decide that whatever God wills or commands is good (cited by Brody, 1977, p. 128).

Needless to say, this position of Moody's suffers from some serious logical defects. Only two other researchers, Ring (1980) and 
Some Logical Problems and Questions

Rosen (1975), have written on this question. Unfortunately, their data seem to be conflicting. Ring argues that near-suicide experiences are essentially identical to near-death experiences. Rosen contends that all of his subjects reported peaceful and tranquil feelings during their jumps, as well as overwhelmingly positive transcendent experiences. None of Rosen's subjects, however, experienced panoramic visions, as well as many of Ring's other core elements. This question of the relationship between suicide and near-death experiences deserves more systematic attention than it has thus far been given.

How do transcendental interpretations of near-death experiences affect traditional Judeo-Christian beliefs about survival after death?

In order to understand what this question involves we have to get clear on just what survival after death has amounted to in the history of the Judeo-Christian faiths. In doing this we find ourselves in the midst of a number of vexing problems. Perhaps the most interesting of these can be understood by looking at the two figures below:
(A) Edna
sleeping
but will
(B) Ralph
some day
gone to
his
meet her
eternal
maker
reward

Both figures $\mathrm{A}$ and $\mathrm{B}$ are reasonable representations of tombstones I have seen in New Haven, Connecticut. At first glance neither figure seems particularly interesting. When you consider, however, that Edna and Ralph were married to each other and, in fact, are buried side by side, the inscriptions on the stones are incongruous. Ralph is "gone," but Edna, curiously enough, is "sleeping." This discrepancy arises precisely because there are two views of survival after death in the Judeo-Christian tradition.

Edna's variety, "resurrection of the body," developed in Hebraic literature over a long period of time and came to fruition in the writing of the Apocalyptic books. (Daniel, c. 165 B.C. is probably the best example of this literature.) It consists in the belief that, at the end of time, the bodies of the dead will be resurrected from the grave and reconstituted. This belief started as a hope voiced by the Prophets, who awaited a vindication of the justice and righteousness of Yahweh in a time when the land would be restored and the political yoke that held them in bondage would be lifted.

By the time of the writing of Isaiah (700-400 B.C.), the realization 
began to be made that this vindication would not occur here and now, but rather would be postponed to the future.

$\mathrm{O}$, Lord, in distress they sought thee,

they poured out a prayer

when thy chastening was upon

them.

Like a woman with child,

who writhes and cries out in

panges,

when she is near her time,

so were we because of thee, $\mathrm{O}$ Lord;

we were with child, we writhed

we have as it were brought forth

wind.

We have wrought no deliverance in

the earth,

and the inhabitants of the earth

have not fallen.

Thy dead shall live, their bodies

shall rise.

For thy dew is a dew of light, and on the land of the shades thou

will let it fall. (Isaiah, 26:19)

A century and a half later, after countless hardships and tragedies, the author of Daniel echoes the same hope when he says, "And many of these who sleep in the dust of the earth shall awake..." (Daniel, 12:2). The logic of these passages is quite simple: Since God has not vindicated himself here and now, it must occur in another life. For the Hebrew people of the Apocalyptic period, this new life consisted of a resurrection of the body.

The origin of the idea of resurrection is a question of continuing debate. Harris Birkland (1926) has argued that the ancient Jews borrowed the idea from the Persians during the period of the Persian domination. Others have claimed that the notion is taken from the Baal cults of the Canaanites, complete with their dying and rising gods. A third position, which to me seems most plausible, is that the Jews, during the time of the Prophets, began to experience a sharpened sense of the importance of the individual. This, coupled with repeated demonstrations that Yahweh would not make good the covenant in the present, produced the notion of survival after death in Hebrew thought. Because God was still thought to be just 
and righteous, even in the face of these continuing inequities, vindication came to be understood as occurring in a life to come. It was faith in the just and powerful Creator that brought solace in the face of death.

The other form of survival after death, "immortality of the soul," is epitomized in figure B. Although there are many varieties of belief in immortality, the chief emphasis is always on a dualism in the human person of body and soul. The body is subject to corruption because it is mortal. It will begin to decay at the moment of death. The soul, however, is immortal and not subject to death. It continues to have life apart from the body. It is this nonmaterial element, the soul, that is important, for it continues to exist unencumbered by the body.

The concept of immortality of the soul is not originally a Biblical notion. The idea pervaded Orphic thought in ancient Greece and was developed most fully by Plato in the Phaedo. As early Christianity came in to contact with Hellenistic and Roman cultures, the nation of immortality slowly made its way into the Church. It may have originally entered the Christian tradition as a specific attempt to describe hope for eternal life in terms of Greco-Roman categories. It is clearly very different, however, from the Hebraic strain of Christian thought that stresses resurrection of the body.

One of the first mentions in Christian literature of the concept of immortality of the soul can be found in Irenaeus's Against Heresies (1977). This document was written by the Bishop of Lyons as a response to gnostic heresies of Marcion and others of the second century. In Book V Irenaeus attempts to deal with the problem of what happens to the individual in the interim between death and resurrection. His answer incorporates a limited notion of the soul, but it is only animated when it is tied to the body. In this text Irenaeus has gone well beyond the New Testament in terms of his willingness to accept Hellenistic ideas regarding survival after death. Metaphysical interpretations of NDEs are more or less tied to this dualistic view of the self. Ironically, this point of view is not to be found in Biblical literature.

It should be clear that a number of natural questions follow from the transcendental interpretation of NDEs. If this is the proper interpretation of NDEs, should we devalue the Biblical point of view? Indeed, what should we do with the celebration of Easter? The empty tomb is superfluous or redundant. There is no need for Easter if we are immortal. 
Can near-death experiences ever give us proof for continued survival after death?

This question is directly related to the last.

The Biblical tradition speaks of a hope for resurrection; it says little about filling clipboards full of information about spirits who have floated back from the dead because, in principle, resurrection is unverifiable. If resurrection occurs at the end of time, we certainly cannot show "now" that it will be certainty "then." Hope for resurrection follows as a corollary to belief in a good and loving God. If life after death were a matter of certainty, there would be no need for faith. Many people having NDEs seem to confuse knowing and believing, but these individuals have little more than personal assurance, which brings us precisely to what faith is all about. Faith is not a matter of fact, it is a matter of internal assurance-an assurance that frequently lives very close to doubt. Sren Kierkegaard (1941) realized this only too well. He spent a considerable amount of his time combating the clergy of his day who also insisted on proofs for the existence of God and the afterlife. Little did he know that a century later people would still be trying to establish rational grounds for believing in the afterlife. He understood that the person of faith is more like a lover than a scientist:

But does thou believe it could occur to him (the lover), dost thou believe that it would be an abomination to him, to talk in such a way as to try and prove by three reasons that there is after all something in this thing of being in love?-pretty much as when the parson proves by three reasons that it is profitable to pray, so that this thing of prayer has sunk so low in price that there must be three reasons alleged to being it a little but into repute (p. 167).

Kierkegaard points to an error many NDE researchers make. They don't seem to realize that the awareness of the afterlife is not like the awareness of a mathematical formula. Mathematics remains valid independent of our observation of it. Love and faith are only meaningful in the minds and hearts of people.

Just how this experiential knowledge of God and the afterlife relates to ostensible evidence can be seen in the following example from John Wisdom (1944-45):

Two people return to their long neglected garden and find among the weeds a few of the old plants surprisingly vigorous. One says to the other, "It must be that a gardener has been coming and doing something about these plants." Upon inquiry they find that no neighbour has ever seen anyone at work in their garden. The first man says to the other, "He must have worked while people slept." The other says, "Look at the way these are arranged. There is purpose and a feeling for beauty here. I believe that 
someone comes, someone invisible to mortal eyes. I believe that the more carefully we look the more we shall find confirmation of this." They examine the garden ever so carefully and sometimes they come on new things suggesting the contrary and even that a malicious person has been at work. Besides examining the garden carefully they also study what happens to gardens left without attention. Each learns all the other learns about this and about the garden. Consequently, when after all this, one says, "I still believe a gardener comes," while the other says, "I don't," their different words now reflect no difference as to what they have found in the garden, no difference as to what they would find in the garden if they looked further and no difference about how fast untended gardens fall into disorder (pp. 188, 190).

What is instructive about this example is that both men agree as to which organic items in the garden can be properly referred to as "weeds" and which should be called "roses." There is no disagreement between the men as to how the garden looks. The difference comes in how that evidence is to be interpreted. This story of Wisdom's may serve as an appropriate analogy for how one might view ostensible proof for survival after death. In Wisdom's example we find out far more about the two men than we do about the gardener. Similarly, the study of near-death experiences may tell us considerably more about the people having these experiences, and the researchers and academicians writing about them, then it does about survival after death. What is perhaps more important, however, is that the issue of survival after death may in principle be one that is clouded in obscurity and possibility. And perhaps it is best that way.

\section{NOTES}

1. Kenneth Ring, personal communication, May, 1981.

\section{REFERENCES}

Birkland, H. Israel: Its Life and Culture. London: Oxford University Press, 1926.

Braude, S. The Holographic Analysis of Near-Death Experiences: The Perpetuation of Some Deep Mistakes. Essence, Vol. 4, in press.

Eliade, E. The Dream of Scipio. In From Primitives to Zen. New York: Harper and Row, 1967.

Evans-Wentz, W. Y. (ed.) The Tibetan Book of the Dead. Oxford: Oxford University Press, 1960.

Hastings, J. Encyclopedia of Religion and Ethics. New York: Scribners, 1928. 
Kalish, R. Contacting the Dead: Does Group Identification Matter? In Kastenbaum's Between Life and Death. New York: Springer, 1979.

Kastenbaum, R. Death Through a Retrospective Lens. In Between Life and Death. New York: Springer, 1979.

Kierkegaard, S. The Sickness Unto Death. Princeton: Princeton University Press, 1941.

Kubler-Ross, E. Interview in Psychology Today, Sept., 1976, 48-56. Kuhn, T. The Structure of Scientific Revolutions. Chicago: University of Chicago Press, 1962.

Moody, R. Life After Life. Atlanta: Mockingbird Press, 1975.

Moody, R. Reflections on Life After Life. Atlanta: Mockingbird Press, 1977.

Nielson, K. In B. Brody's Beginning Philosophy. New York: Prentice Hall, 1977.

Noyes, R. Depersonalization in the Face of Life-Threatening Danger:

A Description. Psychiatry, 1976, 39, 19-27.

Noyes, R. Depersonalization in the Face of Life-Threatening Danger:

An Interpretation. Omega, 1976, 7, 103-114.

Osis, K. Deathbed observations by physicians and nurses. New York:

Parapsychological Foundation, 1961.

Osis, K., and Haraldsson, E. At the Hour of Death. New York: Avon, 1977.

Pribram, K. H. Languages of the Brain. Englewood Cliffs, New Jersey: Prentice Hall, 1971.

Pribram, K. H. Problems concerning the structure of consciousness.

In N. C. G. Globus et al. (eds.), Consciousness and the Brain. New York: Plenum, 1976.

Rawlings, M. Beyond Death's Door. Nashville: Thomas Nelson, 1978. Ring, K. Life At Death: A Scientific Investigation of the Near-Death Experience. New York: Coward, McCann, \& Geoghegan, 1980.

Roberts, A. (ed.) Against heresies. In Anti-Nicene Fathers. Buffalo: Christian Literature Publishing Co., 1977.

Rodin, E. The Reality of Death Experiences: A Reply to Commentaries. Anabiosis, 1981, 2(3), 15-16.

Rosen, D. Suicide Survivors. Western Journal of Medicine, 1975, 122, 289-294.

Rouse, P. G. (trans.) The Ethypro. In Dialogues of Plato. New York: Mentor Books, 1950.

Russell, B. Religion and Science. London: Oxford University Press, 1935.

Sabom, M., and Kreutziger, S. A. Physicians evaluate the near-death experience. Theta, 1978, 6(4), 1-6. 
Near-Death Experiences:

Some Logical Problems and Questions

Teresa, Saint. Interior Castle. In The Complete Works of Saint Teresa of Jesus, Vol. II. New York: Sheed and Ward, 1946.

Wisdom, J. Gods. Proceedings of the Aristotelian Society. London: 1944-1945.

Requests for reprints to:

Dr. Stephen Vicchio

College of Notre Dame

Charles Street and Homeland Avenue

Baltimore, Maryland 21210 